\title{
Climate change during the COVID-19 outbreak: scoping future perspectives
}

\author{
Muhammad Usman ${ }^{1} \cdot$ Mudassir Husnain ${ }^{1} \cdot$ Aimon Riaz ${ }^{1} \cdot$ Areej $_{\text {Riaz }}{ }^{1} \cdot$ Yameen $_{\text {Ali }}{ }^{1}$ \\ Received: 11 January 2021 / Accepted: 20 April 2021 / Published online: 2 May 2021 \\ (C) The Author(s), under exclusive licence to Springer-Verlag GmbH Germany, part of Springer Nature 2021
}

\begin{abstract}
Neither war nor recession or any kind of prior disaster has been considered a prelude to the looming threat of climate change over the past era as coronavirus (hereafter COVID-19) has in only a few months. Although numerous studies have already been published on this topic, there has not been compelling evidence critically assessing the impact of COVID-19 by and on climate change. The present study fills this gap by taking a more holistic approach to elaborate factors, e.g., natural and anthropogenic factors, ocean submesoscales, radiative forces, and greenhouse gas $/ \mathrm{CO}_{2}$ emissions, that may affect climate change in a more prevalent and pronounced manner. Based on the statistical data collected from the NASA Earth Observatory, the European Space Agency, and the Global Carbon Project, the findings of this study reveal that the climate/environment has improved during COVID-19, including better environmental quality and water quality with low carbon emissions and sound pollution. In the lockdown during the epidemic, the emissions of nitrogen dioxide $\left(\mathrm{NO}_{2}\right)$ and carbon dioxide $\left(\mathrm{CO}_{2}\right)$ significantly decreased because of the lower usage of transportation, decreased electricity demand, and halted industrial activities. The policy implications of this study suggested that keeping the climate healthy even in the post-COVID-19 era is a serious concern that needs to be addressed by investing in clean and green projects, ensuring green energy evolution, dealing with a large volume of medical waste, building health-ensuring and livable societies, and halting the funding of pollution. For governmental and regulatory bodies, these factors will provide a strong foundation to build safer, healthier, and environmentally friendly societies for generations to come.
\end{abstract}

Keywords Coronavirus (COVID-19) $\cdot$ Climate change $\cdot$ Post-COVID-19 era $\cdot \mathrm{NO}_{2}$ and $\mathrm{CO}_{2}$ emission

\section{Introduction}

We are facing the greatest pandemic that humans have faced in history (Nicola et al. 2020). The entire world desires by hook or by crook to be safe from the disastrous impacts of COVID-19 (Shen et al. 2020). An increasing number of infectious diseases, such as HIV/AIDS, SARS, MERS, and Ebola, have spread from wildlife to humans, and it has been evident that COVID-19 has been transmitted by the same route (Usman et al. 2020). COVID-19, a single-stranded

Responsible Editor: Eyup Dogan

Muhammad Usman m.usman@ue.edu.pk

1 Department of Economics and Business Administration, Art \& Social Sciences Division, University of Education Lahore (Faisalabad Campus), Faisalabad, Pakistan
RNA virus, has a diameter ranging from 80 to $120 \mathrm{~nm}$. The first case was reported in December 2019 in Wuhan, Hubei Province, China, and most initial cases had a source of infection from a seafood market (Chakraborty and Maity 2020; Huang et al. 2020).

From the last century onwards, the world has continuously changed due to industrialization, which provides a wide variety of products at a lower price but has caused environmental changes (Pearson and Foxon 2012). The Earth has been facing environmental challenges for decades, even though environmental issues have been the most important issues and have been at the top of the UNGA (United Nations General Assembly) agenda since their meeting in 2019 (Fritz et al. 2019). Because of this massive industrial growth, the land, air, and water are all contaminated through industrial waste, which causes the inhabitants of the water to be in a lifethreatening environment. Moreover, air pollution causes seven million premature deaths each year according to WHO estimates. Poor air quality increases the risk of mortality from 
severe and chronic diseases, such as stroke, heart disease, chronic obstructive pulmonary disease, lung cancer, and acute respiratory infections. It has also become a major killer, contrary to malaria, violence, HIV/AIDS, drugs, alcohol, traffic accidents, and so on (Bornstein 2020).

COVID-19 is a widespread pandemic of our time; from the end of last year until today, a significant number of people have died due to this viral outbreak (Roser et al. 2020). Hundreds of thousands have been effective, economies have been in a nose-dive, and people have suffered from social, economic, emotional, mental, and physical illness or disturbances to their lives on all levels (Tian et al. 2020). Numerous elements can be considered to evaluate the worsening situation. Environmental challenges are some of them and play a significant role in the spread of COVID-19 (Muhammad et al. 2020). For example, a study by Harvard found that Italy, France, Spain, and Germany have had $78 \%$ of deaths from their five most polluted areas (Wu and Nethery 2020).

The pandemic (COVID-19) has also indicated the importance of focusing on another global crisis, i.e., climate change. What can one natural crisis teach us about another crisis? The surprising COVID-19 epidemic has demonstrated how the problems of the human race are linked with each other. As per the recent SDGs (Sustainable Development Goals) statement, climate change is the most crucial and serious matter on the 2030 agenda because it could bring future catastrophic incidents and can have irreversible effects. Therefore, this study contributes insight into both this natural crisis and how the nexus between COVID-19 and climate change has emerged.

According to the available statistical data, the total direct cost of the six major epidemics (hantavirus, influenza, Ebola virus, etc.) was approximately 2 billion dollars, and the indirect economic cost was beyond estimates. Similarly, in the current scenario, due to the COVID-19 pandemic, almost all kinds of economic sectors (such as industrial, transportation, tourism) are facing significant losses in both developed and developing countries. However, a substantial reduction in the demand for fossil oil and electricity is being reported (e.g., $18.17 \%$ decline in $\mathrm{CO}_{2}$ emission, $19.30 \%$ decline in $\mathrm{NO}_{\mathrm{x}}$ ), which can positively affect the environment and climate change (Kumar and Ayedee 2021). It is also necessary to draw effective policies to create a balance between economic progress and a healthy environment/climate. Therefore, in this study, we focus on the environmental side of COVID-19. We will understand the nexus between COVID-19 and environmental challenges. Last, we will come up with some of the important points that can help us to control pandemics of this kind in the future.

The rest of this study is structured as follows. The "Literature review" section presents a review of the most recent literature on this topic. The "Factors affecting climate change" section describes the elements affecting climate change. The "Nexus between COVID-19 and climate change" section discusses the nexus between COVID-19 and climate change. The "Sustainable climate change in the post-COVID19 era" section enlightens the steps that need to be taken after COVID-19 to make the world a better environmental place. The "Conclusion" section concludes this study by providing some limitations, policy implications, and future research directions.

\section{Literature review}

As COVID-19 causes massive destruction in terms of human health, the World Health Organization has declared medical emergencies around the globe. The abrupt attack by COVID19 is related to a more serious global climate crisis. Researchers are trying to explore the relationship between COVID-19 and climate change. In a study in Pakistan, Mehmood et al. (2021) investigated the association between COVID-19 and climatic elements. Using GLM (generalized linear model) and GRA (gray relational analysis) techniques, the authors reported a statistically significant association between COVID-19 cases and climatic factors.

In a study on Middle Eastern countries (i.e., Israel, Jordan, and Palestine), Negev et al. (2021) evaluated the role of COVID-19 and adaptation to climate change. Based on the geographical location of Israel and Palestine, it is unavoidable to control the transmission of the virus. However, Jordan can close its borders and can stop the spread of the virus. The findings of the study suggested that the intensity of the virus spreading can be minimized through proper adaptation to climate change, data sharing, and effective health systems and surveillance. In a review article, Marazziti et al. (2021) have documented the nexus between COVID-19, change in climate and environmental pollution, as these factors also have an impact on mental health. The current pandemic has proven the narrative that our ecosystem is weak and fragile, and we are also unable to protect ourselves from pollutants.

The recent epidemic of COVID-19 has raised several questions regarding climate change, the environment, and the future of our health. In this regard, the HERA (Human and Environmental Risk Assessment)-COVID-19 working group and Barouki et al. (2021) aimed to inspect the need for research on COVID-19 and its environmental and climatic consequences. It was found in the study that the development and spread of COVID-19 appeared because of massive urbanization, demolition of habitat, fragile environmental change, animal trading, and global travel. In a qualitative study based on the media coverage of COVID-19 from January to June 2020, Contreras et al. (2021) discussed six important lessons that can be drawn from the COVID-19 epidemic. The main lessons comprised the reduction in the usage of fossil fuel and greenhouse emissions, rapid response, sustainable environment, 
trust in science, the limits of rugged individualism, and the opportunity for greater change.

Almost all countries in Europe have faced the wave of the COVID-19 pandemic starting in February 2020. In a study from Spain, Fernández-Ahúja and Martínez (2021) explored the linkage between the spread of the COVID-19 virus and environmental factors such as temperature, air pressure, rainfall, and sunlight hours. By collecting data from different provinces and using a linear regression model, the findings of their study supported the authors' point of view, i.e., there is a strong connection between COVID-19 and environmental elements. Moreover, the results also showed that cold regions suffered more than warm regions. In a review article, Nguyen et al. (2021) discussed how climate change reacts in the presence of COVID-19. Due to the pandemic situation, countries adopted lockdown strategies to save their citizens from the drastic impact of the virus. Consequently, a sharp decline was reported in $\mathrm{CO}_{2}$ emissions. Likewise, a positive effect was also evident because of less production and limited travel between cities and regions.

The entire world is suffering from climate change and COVID-19; therefore, preemptive actions need to be taken to reduce their severity. In a review article, Kumar and Ayedee (2021) inspected the liaison between climate change and COVID-19 and their sustainable solutions. The data were taken from secondary sources, i.e., news reports and the previous literature. The results of their study suggested that lockdown is only a short-run solution for COVID-19, which reduces pollution and the issue of climate change. However, it is harmful to long-run economic growth. Therefore, in the long run, countries need to find suitable solutions to counter both COVID-19 and climate change. Bertram et al. (2021) reported that COVID-19 has a deep impact on energy systems worldwide. A significant reduction is being observed in $\mathrm{CO}_{2}$ emissions from the power sector. The main reason for this reduction is a sharp decline in electricity demand only due to the COVID-19 economic shutdown. These consequences demonstrate an opportunity for policymakers to accelerate the reduction in power sector emissions.

A Paris climate agreement was made in 2015, and after 5 years, global $\mathrm{CO}_{2}$ emissions have started to decrease. However, according to Le Quéré et al. (2021), the main reason for this effect is none other than COVID-19 lockdowns/shutdowns. In the post-COVID-19 world, new and effective environmental policies need to be drawn to sustain the decline in worldwide emissions. The terrible COVID-19 outbreak in China is now becoming a global crisis by adversely affecting a large population of the world. Therefore, new preventive measures are adopted together with social distancing to avoid its extreme effects. Manzanedo and Manning (2020) stated that COVID-19 has disturbed almost every aspect of daily life and work and has largely crushed the world economy. Furthermore, this emergency also provides an exceptional understanding of how the worldwide climatic crisis could be managed, as the overall consumption of fossil oil is significantly reduced.

As a threat to the global health system, citizens have been advised to limit their activities and to maintain social distance to minimize the risk from COVID-19. Even though the CDC recommends a distance of $2 \mathrm{~m}$, studies have reported that droplets trapped inside a turbulent puff can be transported up to $8 \mathrm{~m}$. Luis A Anchordoqui et al. (2020) investigated the transportation of the COVID-19 virus through the air and the role of temperature in this relationship. By using an analogy-based model, the findings of their study showed that temperature variation can impact the puff, halting its range by using extreme ambient cold or heat. By using a mathematical modeling approach, Rasheed et al. (2021) explored the relationship between Indian medicine (Ayurveda) and PersianArabic medicine (Unani) to prevent and treat diseases including COVID-19. The authors elaborated that individual temperament is a significant factor for personalized medication and the results verified that it is mathematically possible to use Ayurveda and Unani treatment alternatively.

Previous studies recognized that human droplets (i.e., from breathing, sneezing, or coughing) contain numerous cells and several infectious viruses. Luis Alfredo Anchordoqui and Chudnovsky (2020) indicated a physics viewpoint regarding the transmission of airborne germs. By using the fluid dynamics method, the findings of their study provide an alarming situation, i.e., infectious droplets could spread far away from the source of the virus and be more dangerous than those in a nearby location. Thus, strict measures should be adopted to slow down the spread of COVID-19. Furthermore, Ilesanmi and Afolabi (2020) documented the adverse effects of COVID-19 on the health system in Nigeria. The Nigerian Centre for Disease Control (NCDC) and federal government adopted vertical healthcare programs to address COVID-19. Yet, such approach alone has shown unsatisfactory results, and required integrated programs to properly manage COVID-19 situations.

\section{Factors affecting climate change}

Climate change occurs rapidly over time. Only in a decade has Earth's climate changed dramatically (Taylor 2014). The following are the few prominent factors that can deeply impact climate change across the globe (Fig. 1).

\section{Natural vs. anthropogenic factors}

It is believed that the rapid temperature change is due to human activities causing global warming. Climate change is triggered by both natural and anthropogenic forces (Stern and Kaufmann 2014). Natural forces consist of solar 
Fig. 1 Methodological flowchart

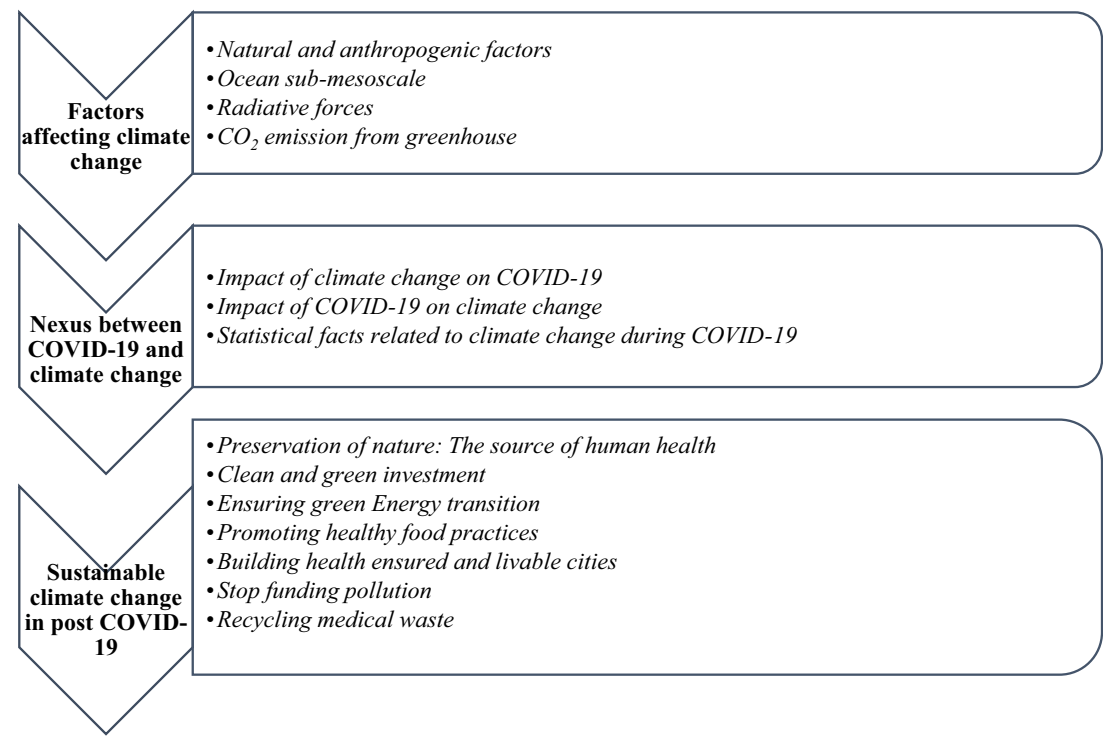

irradiance and stratospheric volcanic aerosols, and anthropogenic factors comprise greenhouse gases and sulfate aerosols (Tett et al. 1999). Previous studies, e.g., Jones et al. (2003), have also reported that, along with natural forces, anthropogenic elements are also critical for causing climate change.

\section{Ocean submesoscale}

Climate change may also be referred to as a change in global heat. Earth's climate may be influenced by changes in the heat of the ocean atmosphere ( $\mathrm{Su}$ et al. 2018). Studies have shown that irregular vertical heat fluxes from colder to warmer waters are led by the motion of the ocean (oceanic waves) related to horizontal scales smaller than $50 \mathrm{~km}$ (called submesoscale). The findings have also suggested that submesoscale undercurrents are crucial for the transport of heat between the interior (ocean) and the atmosphere and are thus the main factors in the Earth's climate.

\section{Radiative forces}

Anthropogenic radiative forces mainly consist of greenhouse gases such as carbon dioxide, methane, $\mathrm{N}_{2} \mathrm{O}$, chlorofluorocarbons, and tropospheric ozone (Stevenson et al. 1998). Tropospheric sulfate aerosols are due to clear air, in addition to cloudy air radiative forces. Stratospheric ozone forces are induced by depletion in the ozone layer (Andronova and Schlesinger 2000). The $\mathrm{SO}_{2}$ gas injected into the stratosphere by major volcanic eruptions creates stratospheric sulfate aerosols, causing the scattering of incident solar radiation back to space and resulting in major volcanic radiative forces (Andronova and Schlesinger 2000).

\section{Greenhouse $\mathrm{CO}_{2}$ emissions}

Previous studies have shown that anthropogenic forces also include greenhouse gas emissions (Tett et al. 1999). The heat circulation is affected by upsurges in atmospheric greenhouse gas concentrations (Wood et al. 1999).

\section{Nexus between COVID-19 and climate change}

We analyze the relationship between COVID-19 and climate change from both perspectives, i.e., the impact of climate change on COVID-19 and vice versa.

\section{Impact of climate change on COVID-19}

The novel coronavirus has been declared a pandemic by the World Health Organization after spreading to most parts of the globe. Whereas the influenza virus shows some alteration with seasons, it is unknown if COVID-19 has any seasonal influence (Bukhari et al. 2020). According to the World Health Organization, the pandemic could even affect tropical countries that have scorching temperatures (Acosta et al. 2020). Alternatively, several other theories have also been presented regarding the effects that will cause a change in the widespread COVID-19. Some other viruses of the same family (respiratory syndrome viruses) are unlikely to survive in hot, humid, and warm climates. Therefore, scientists had believed that the virus (COVID-19) would not last until June-July or August (Khan et al. 2020).

The growing rate of COVID-19 around the world is negatively related to warm and humid seasons. Transmission of the virus from one person to another is affected by temperature. Moreover, Pakistan, a tropical country, found fewer COVID- 
19-positive cases than the cold and dry regions (Bukhari et al. 2020). It is also under consideration that high temperature kills most viruses, but few claims are being made regarding no effect or, in relation to warm and humid temperatures, to the multiplication of the virus (Khan et al. 2020). While the spread of the virus may be slowed down because of warm weather, it is not sufficient to depend on climate change alone (Brassey et al. 2020).

In contrast, it was found that the activity and development of the MERS virus (virus from the same family) were greatly induced by climate change. During the study period, it was found that multiple peaks of MERS occurred during the hot season (April-August). This conclusion opposes the Gardner et al. (2016) study, where they stated that lower temperature is linked with elevated hazards in primary MERS-COV infections (Altamimi and Ahmed 2020). Therefore, the studies also verified that climate change or seasonality may not affect or correlate with the change in widespread COVID-19. Now, it is not considered that warm weather could cure or put an end to the spread of COVID-19 (Acosta et al. 2020).

\section{Impact of COVID-19 on climate change}

The most important thing for us, to begin with, is that we never want to see these kinds of environmental benefits associated with such tremendous human suffering. The COVID19 pandemic has a direct impact on climate change. There are several climate changes as a result of the pandemic. The air we breathe has become clearer as there is less emissions of pollutants in the air because of lockdowns. Climate could modulate the spread of the pandemic, and climate change could have led to the emergence of the novel corona virus (Ching and Kajino 2020).

Although COVID-19 has caused many difficulties in the lives of people while performing their daily activities, it has also caused a number of changes in the air that we breathe and live in. Nitrogen dioxide is a dangerous gas that is emitted from the burning of gasoline, coal, diesel in vehicles, power plants, and industrial facilities. Near ground $\left(\mathrm{NO}_{2}\right)$ can turn into ozone and make air hazy and unable to be breathed (NASA 2020). Nitrogen dioxide is known to cause several diseases that are fatal to humans. It is known to cause troubled breathing in people. It makes it difficult for people to breathe and is likely to cause lung cancer (Al-Ahmadi and Al-Zahrani 2013). However, a lockdown seems to impact the climate in a positive way in regard to the emission of $\mathrm{NO}_{2}$. In China, due to the lockdown of major cities' transportation and industrial units, the nitrogen emission rate has fallen rapidly.

Due to the lockdown, it was estimated that global carbon dioxide $\left(\mathrm{CO}_{2}\right)$ emissions from fossil fuels decreased by $7 \%$ in 2020. After the Second World War, this decline was seen as a major relative decline in emissions. All the world's major emitters have reported a decline in the emission of fossil
$\mathrm{CO}_{2}$, including $11 \%$ in the European Union, $1.7 \%$ in China, $12 \%$ in the USA, and 9\% in India (World Economic Forum, 2020). Nevertheless, researchers argue that a fall in emissions in 2020 may not slow the pace of global warming. Compared with 2019 , a decline of $2.4 \mathrm{GtCO}_{2}$ was recorded and the latest estimates suggest that emissions will be regulated at 34 bn tons of $\mathrm{CO}_{2} \mathrm{GtCO}_{2}$ (Friedlingstein et al. 2020). This annual decline is the largest drop in emissions ever recorded according to researchers.

\section{Statistical facts related to climate change during COVID-19}

The maps below show the change in the emission level of nitrogen dioxide $\left(\mathrm{NO}_{2}\right)$ after the COVID-19 outbreak. Figure 2 shows the level of $\mathrm{NO}_{2}$ in the central and eastern parts of China from January 1 to January 20 and from February 10 to February 25 (NASA 2020).

Figure 3 shows the changes in $\mathrm{NO}_{2}$ emissions between two different time periods. The orange areas show an increase in the level of $\mathrm{NO}_{2}$. However, the blue areas show decreases, such as in India and Bangladesh, which were still under quarantine (NASA 2020). It has been observed that $\mathrm{NO}_{2}$ emissions have fallen by almost half in many European cities (Bruyninckx 2020). The nitrogen dioxide $\left(\mathrm{NO}_{2}\right)$ emission level has dropped as a result of the lockdown in cities. It has been noted that the emission level of nitrogen dioxide has dropped by $54 \%$ in Paris and $49 \%$ in Rome (Morrison 2020). Data from the European Space Agency Copernicus Sentinel show that some cities in Europe have had a drop of $45 \%$ in the emission level of $\mathrm{NO}_{2}$ since the outbreak of COVID-19.

It has been reported that COVID-19 has not only impacted the emissions of nitrogen but has also reduced the emissions of carbon gases (Fig. 4). There is a daily $11-25 \%$ emission of carbon gases. The decrease in industrial activities and transportation is the main cause for the reduction in carbon emissions in the atmosphere (Cho 2020). In a dozen or more countries, due to enforcing the COVID-19 lockdown, a wide range of transport use, electricity demand, and industrial activities have been reduced, which has ultimately lowered $\mathrm{CO}_{2}$ emissions (Evans 2020).

It has been discovered that air pollution affects the health of humans. These health effects are severe enough to include increased hospital admissions due to the exacerbation of cardiac and respiratory diseases (Karimzadegan et al. 2008). The reduction in travel through the air also seems to have had a positive impact on the climate. A reduction in air travel has reduced the emissions of greenhouse gases (Kingham 2020). A recent study found that people living in places in which the quality of air is poor are more likely to die from COVID-19 (Wu et al. 2020).

Figure 5 provided by the OECD shows the mortality rate in 2005 and 2010 due to air pollution, with China and India being a major constituent of the mortality rates due to poor 


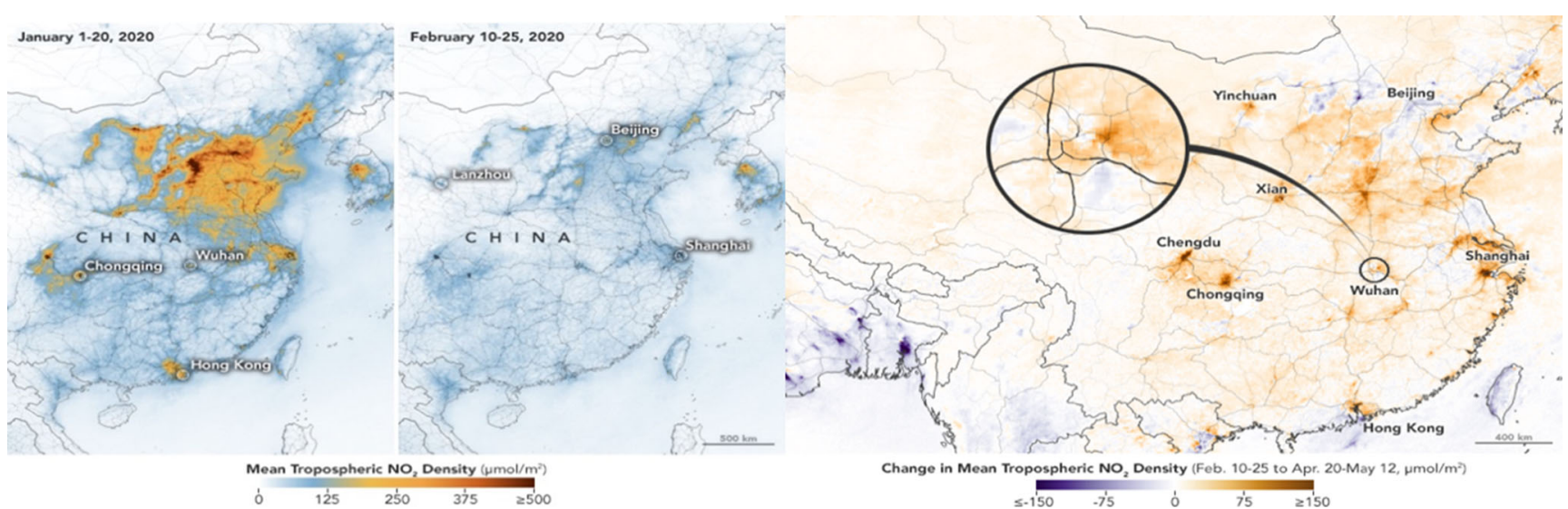

Fig. 2 Decrease in $\mathrm{NO}_{2}$ emissions in China during the lockdown (source: NASA Earth Observatory)

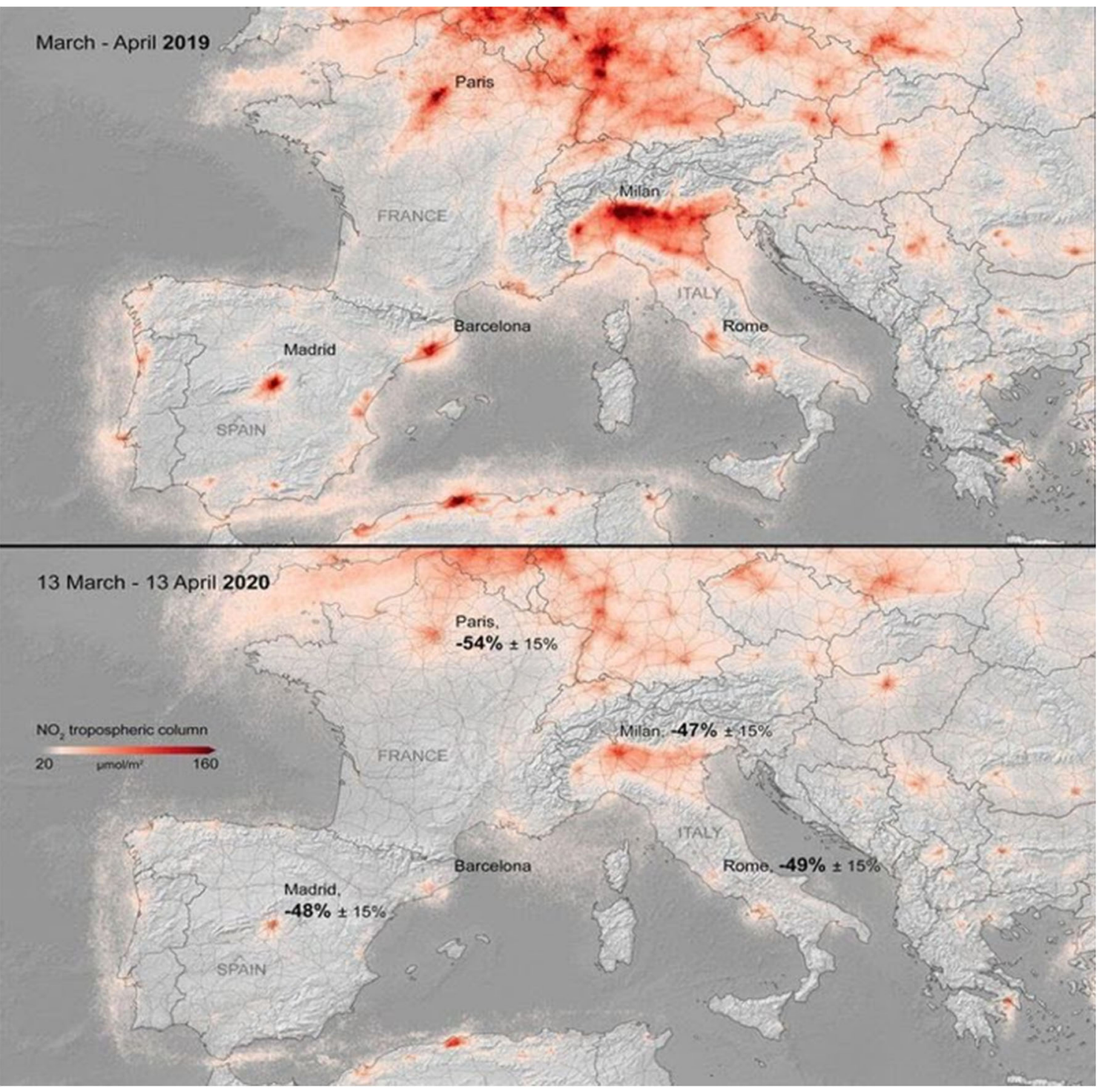

Fig. $3 \mathrm{NO}_{2}$ emissions between two different time periods (source: European Space Agency) 
Fig. 4 Global daily fossil $\mathrm{CO}_{2}$ emissions (source: Nature Climate Change (2020) Global Carbon Project)
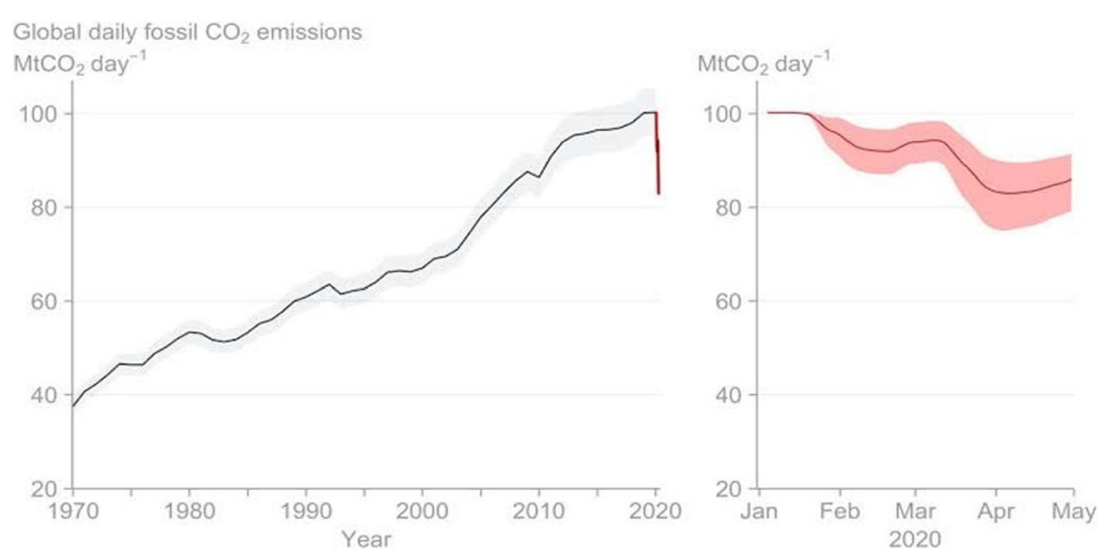

air quality. In 2005, it was shown that China had a mortality rate of $1,200,000$, and India showed a mortality rate of 600,000 . As of 2010 , the mortality rate of China reached $1,200,000$ and that of India reached 700,000. The rest of the world had a mortality rate of 900,000 in 2005 and approximately $9,500,000$ in 2010 .

It has been found that annually, 5.5 million people die prematurely every year due to indoor air pollution, with half of the deaths occurring in China and India (BBC, 2016). A cleaner environment and air quality during the lockdown due to the pandemic has demonstrated that human society must improve the quality of the air (Ching and Kajino 2020). It was reported that 4.2 million deaths worldwide are caused by ambient air pollution. Air pollution contributes to $26 \%$ of deaths due to respiratory infection, $25 \%$ of deaths due to chronic obstructive pulmonary disease (COPD), and $17 \%$ of ischemic heart disease and stroke (WHO 2016).

It has been shown that COVID-19 affects more people with pre-existing diseases than healthy people. It is worth noting the mortality rate of a person with a pre-existing disease before they have been diagnosed with COVID-19 compared with healthy patients before COVID-19 (Isaifan 2020). In this regard, Table 1 clearly shows the difference in the mortality rate of people with pre-existing conditions and the mortality rate of people without pre-existing conditions. It shows that people with pre-existing conditions have a higher chance of mortality after testing positive for COVID-19 than people without preexisting conditions.

As discussed in the "Literature review" section, previous literature also supports our narrative; for example, Mehmood et al. (2021) found a significant association between COVID19 cases and climatic factors in Pakistan. Similar results have been found by Negev et al. (2021) in Middle Eastern economies. Consistent evidence was shown by Fernández-Ahúja and Martínez (2021) in Spain. Azuma et al. (2020) observed the same phenomena in 28 regions of Japan. Bashir et al. (2020) reported that the air quality in New York City also improved during the COVID-19 lockdown.

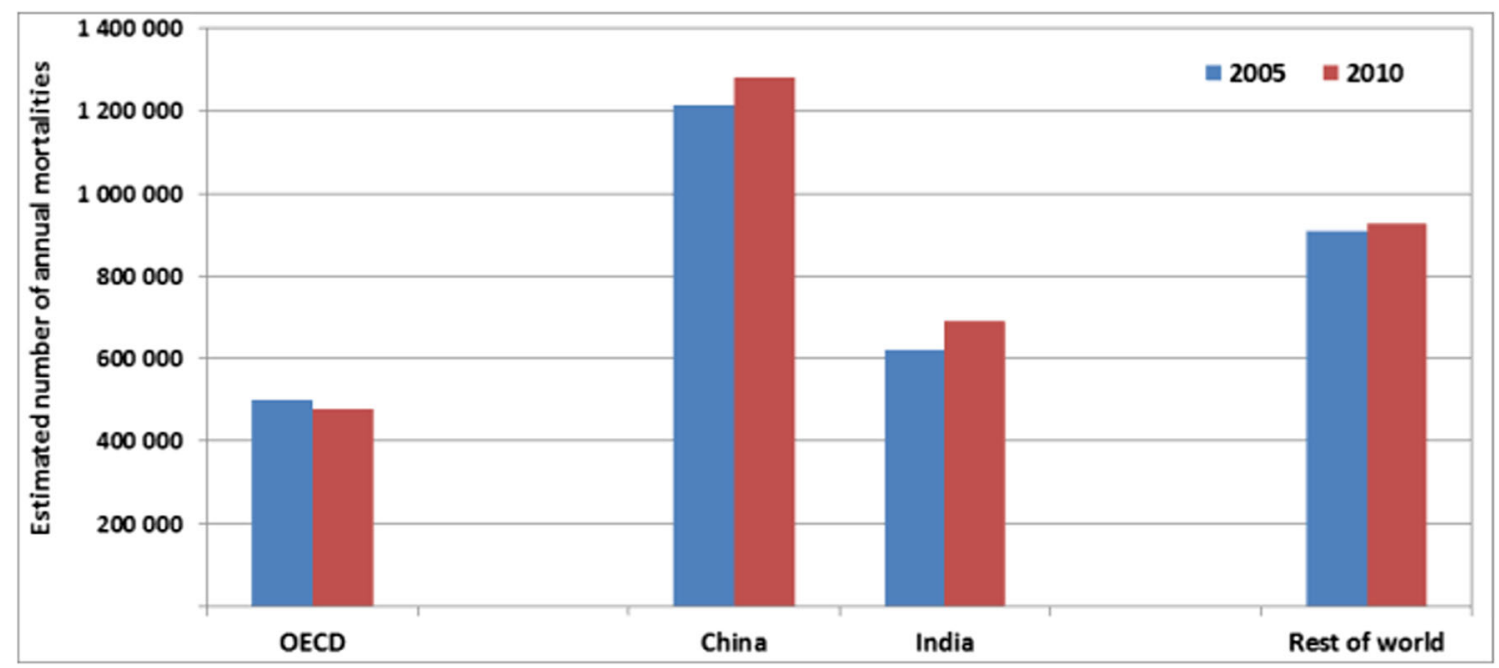

Fig. 5 Number of casualties due to air pollution (source: OECD) 
Table 1 The mortality rate of people with pre-existing vs no pre-existing conditions (source: World-O-Meter, 2020)

\begin{tabular}{lll}
\hline Pre-existing disease & $\begin{array}{l}\text { Death rate (mortality rate) } \\
\text { (Confirmed cases) }\end{array}$ & $\begin{array}{l}\text { Death rate (mortality rate) } \\
\text { (All cases) }\end{array}$ \\
\hline Cardiovascular diseases & 13.2 & 10.5 \\
Diabetes & 9.2 & 7.3 \\
Chronic respiratory diseases & 8.0 & 6.3 \\
Hypertension & 8.4 & 6.0 \\
Cancer & 7.6 & 5.6 \\
No pre-existing conditions & & 0.9 \\
\hline
\end{tabular}

\section{Sustainable climate change in the post-COVID-19 era}

After facing the pandemic, many countries locked down their people and economies, which ultimately has many consequences for humanity to face in the near future (Garrett-Cox 2020). The economies are facing a major downfall worldwide (Usman et al. 2020). Global environmental changes such as soil degradation, ozone layer depletion, pollution, and urbanization are changing the environment and are creating an indisputable threat to humans and the planet Earth (Chakraborty and Maity 2020). Economies are a product of healthy, safe, and sound human societies. These healthy societies rely on natural life, which includes clean air, water, and food. Deforestation, intensive and polluting agricultural practices, unsafe management, and consumption of wildlife undermine and pressure these services (Ghebreyesus 2020).

Sooner or later, as vaccines for COVID-19 become readily available and immunity is developed to fight the pandemic, the word will open up again. However, there is a serious threat that after controlling this situation, the world may again return to adversely impacting the climate. Therefore, in this regard, the following are a few important steps that can be taken after COVID-19 to maintain a healthy climate.

\section{Preservation of nature: the source of human health}

The world has changed in only a matter of months; thousands of people have died, and hundreds of thousands have been infected during this pandemic (Di Renzo et al. 2020). People who have been infected by this virus may not be the same person mentally, and their lives will be changed. In Italy, massive travel restrictions have been made. In London, the busy bars, theaters, and other busy places have been closed, and people have been asked to stay home to stay safe. The majority of flights have been canceled all over the world, with people remaining in homes practicing social distancing and working remotely (Harapan et al. 2020). These steps have helped to preserve nature and have improved human health.

\section{Clean and green investment}

Currently, as people are restricted from going outside their homes, they are self-isolated to make themselves and their families safe from this evil pandemic. People have found some indoor activities; one is indoor gardening, which has increased significantly, and it will be a valuable investment for a healthy and green lifestyle (Minawi 2020). People are well aware and more concerned about the environment today than they were in the past; the survey conducted by FMCG Gurus also had answers about the questions relevant to the environment and sustainability that we have had as an outcome of a clean and green atmosphere, which stood at $55 \%$ and $35 \%$ of the people for the respective factors (Hughes 2020).

\section{Ensuring a green energy transition}

The transition to low carbon emissions and renewable energy seems to be encouraged worldwide. The large fall in the prices of traditional energy sources (oil and gas), which was also facilitated by COVID-19, as a result of the recession and crisis in the world economy objectively supports traditional economic development. It also suggests that there may be a decline in attention regarding sustainable development, implementing UN sustainable development goals, and combating climate change in most countries of the world (Bobylev 2020). It is very important for every country to adopt a way forward that gives more emphasis on green energy, and sustainable, renewable, and ecological means should be used to ensure a nature-friendly environment.

\section{Promoting healthy food practices}

Health is currently a focus, and governments try to ensure that all necessities relevant to the health of their people should be available, but people take steps to be prepared for virulent infections such as COVID-19. Communities throughout the world have turned to natural and pure foods and have tried to avoid canned and processed foods. These behaviors can create new trends for the future (Di Renzo et al. 2020), as evident from a survey conducted by FMCG Gurus in April of this 
year, which shows some relevant trends that $73 \%$ of people are more conscious about healthy foods and drinks, as $57 \%$ people thought about immunity in their considerations. In a question relevant to their diet plan, they answered with the following statistics: $58 \%$ were increasing their daily fruit intake, $45 \%$ were going to decrease their sugar intake, and $37 \%$ were keen to increase their protein intake. While considering all factors in the study, they also surveyed the psychological effects, and they found that $55 \%$ of the consumers consumed healthy food to change their mood as they felt bored and stranded (Hughes 2020).

Another study conducted by IPSOS in the MENA region came out with interesting and some unbelievable statistics that cannot be avoided as far as future trends are concerned. It showed that $54 \%$ eat healthy foods, $52 \%$ are more likely to have immunity-boosting foods, and $45 \%$ of people are eating more balanced diets. As the people have been encapsulated in their homes for a long time, they are changing their habits as some people cook their own food, and some are likely to avoid restaurants and to take their meals outside; the survey presented statistics such as $81 \%$ are trying new recipes, $57 \%$ are preparing their meals, $49 \%$ are watching food and cooking channels, $79 \%$ are eating less at restaurants, $76 \%$ are replacing restaurant food with home-cooked food, and 53\% are still not keen about dining again in restaurants (Minawi 2020). These statistics from recent surveys and studies show a way forward for the food and beverage industry.

\section{Building healthy and livable cities}

The epidemic center in Wuhan City, which has a population of over 11 million, produced 200 tons of medical waste on a single day on the 24th of February 2020, which was four times the capacity to incinerate by the city's only facility in a single day. Medical waste is a major issue, as more medical waste is produced as the virus spreads all over the world. Medical health organizations and waste management corporations have taken steps regarding decontamination services, and governments should also find solutions as soon as possible (Luan and Ching 2020).

All over the world, people are in lockdown such as students and job holders from different industries, but people who clean cities are endangering their lives. These are the most vulnerable groups because they are in direct contact with medical waste from hospitals and homes. The usage of plastic bottles such as hand sanitizers, masks, gloves, and other medical equipment and accessories is increasing daily, causing an increase in waste, which may end up directly in ponds, rivers, and seas (Saadat et al. 2020). In recent years, it has been a normal behavior for people to choose to live in apartments and flats in densely populated cities, but in the post-COVID-19 era, it will be the norm to have an indoor garden, and designing homes with significant exposure to light and fresh air will be an important consideration for city dwellers.

\section{Stop funding pollution}

Pollution is simply tampering with natural ecosystems. In today's post-industrialized world, economies of scale are a common problem, and we have to make the highest number of products to obtain the highest amount of money in our pockets. This horrible greedy behavior in the world prevents us from drinking pure water, inhaling pure air, and eating pure food, and these contaminated pollutants make us feel unhealthy, unhappy, short tempered, and etc. (Rickenbacker et al. 2020). Several studies have extensively analyzed the impact of air pollution, particularly on the death rate caused by COVID-19; e.g., Harvard's study on this topic analyzed 120 cities in China and obtained evidence of the significant link between COVID-19 and pollution. Likewise, among the 66 regions in Italy, France, Spain, and Germany, 78\% were from the most polluted regions, five in number $(\mathrm{Wu}$ and Nethery 2020).

\section{Conclusion}

Currently, there are millions of confirmed cases, and deaths have been increasing every day. The entire world has been in lockdown due to the COVID-19 pandemic. Clarity about the answers to questions such as how we got into this crisis, when will the ongoing restrictions ease and the world will walk again on its own feet, how people will be able to rebuild their societies and economies, and other wider questions and issues should be addressed. There is more uncertainty than a clear view of the picture, which shows stability, growth, improvement, development, and a living environment for all creatures, most importantly humans in this world. Increasing levels of poverty could lead to an increase in legal violations in environmental areas. If there are no funds held by households to maintain even a low standard of living, then poaching, illegal hunting, fishing, and the cutting down of trees will increase (Bobylev 2020).

Climate change occurs rapidly over time. Only in a decade, the Earth's climate can change dramatically (Taylor 2014). Therefore, the purpose of this study is to explore the relationship between COVID-19 and climate change. Based on previous studies, we found several factors that are understood as determinants of climate change, such as natural and anthropogenic factors, ocean submesoscales, radiative forces, and $\mathrm{CO}_{2}$ emissions. Some of the studies have suggested that COVID19 may have a seasonal influence; however, other studies have found that COVID-19 is not stopped through exposure to the sun or temperatures higher than $25^{\circ}$ (Acosta et al. 2020). Therefore, it is recommended that we take preventive 
measures such as quarantining (staying at home) and always washing our hands.

A large number of people have suffered from social, economic, emotional, mental, and physical illnesses or disturbances. However, based on statistical data, it is observed that the COVID-19 pandemic has had a positive impact on the environment/climate. Due to the lockdown, the emissions of $\mathrm{NO}_{2}$ and $\mathrm{CO}_{2}$ have significantly decreased because of the lower usage of transportation, a decrease in electricity demand, and a reduction in industrial activities. Scientists from universities, industries, and governments are trying to develop a suitable vaccine to cure COVID-19. There is a strong belief that sooner or later, we will win the fight against COVID-19, and the word will open up again. However, there is a serious threat that after controlling COVID-19, the world will probably again return to adversely impacting the environment. Therefore, in this study, we also proposed some of the policy factors that need to be observed to keep the climate healthy in the post-COVID-19 era. These policy factors include preservation of nature, clean and green investments, ensuring a green energy transition, promoting healthy food practices, building health through livable cities, and stopping the funding of pollution. These factors will provide a strong foundation to build safe, healthy, and environmentally friendly societies for generations to come.

To mitigate the economic crises caused by COVID-19, nations around the globe are rapidly stimulating their economies. Similarly, equal attention should also be given to climate change, as it also affects human health and prosperity. The findings of this study support the arguments that government strategies regarding COVID-19 have enormously changed the demand for energy consumption around the globe at both the individual and corporate levels. Many countries have not only closed their industries but also restricted the mobility of their citizens. These steps have significantly reduced emissions and have had a positive impact on climate change. As discussed in the "Literature review" section, previous studies have also reported similar results.

Nevertheless, this study highlights the subject that needs to be investigated in greater detail. Based on the conditions that climate change and health systems are currently facing, this paper could be very important in defining a roadmap regarding future climate change and thereby provides implications for policymakers and health professionals to estimate and plan for post-COVID-19 situations. As things improve, there is also an opportunity to ensure a sustainable climate path in the post-epidemic world. It can also provide guidelines for individuals and societies to build a sustainable and healthier environment.

Aside from all the abovementioned implications, this study has some limitations; e.g., in this study, we did not use any empirical models or methodologies to estimate the relationship between COVID-19 and climate change. Future studies can fill this gap. Climate change is a mixture of multiple elements and events. In this study, we examine climate change as a whole; however, potential studies can diversify the elements of climate change and can explore the impact of COVID-19 on each of them. However, at present, as the epidemic is still evolving, it is much more significant to keep the environment safe and healthy and to keep an eye on the consequences. Based on these facts, this study concludes that it is time to think deeply about the aforementioned relationships, not only for our existence but also to maintain a balance between the environment, humans, and animals; otherwise, the consequences will be frightening to glimpse.

Acknowledgements The authors would like to thank Prof. Dr. Chunhui Huo (Dean Asia-Australia Business College, Liaoning University, People's Republic of China) for his insightful comments, and invaluable feedback.

Author contribution MU originated and conducted the research, AR1 completed the literature survey on the topic, AR2 conducted the statistical analysis, YA assisted in compiling the data from the diverse sources, and $\mathrm{MH}$ finalized and prepared the draft.

Data availability Publicly available databases are being used in this study, e.g., World-O-Meter (https://www.worldometers.info), NASA Earth Observatory (https://earthobservatory.nasa.gov), European Space Agency (https://www.esa.int), and Global Carbon Project (https://www. globalcarbonproject.org).

\section{Declarations}

Ethics approval and consent to participate Ethical approval is not applicable. For this study, we used publicly available data; therefore, no consent from the participant was required.

Consent for publication No publication consent is required.

Competing interests The authors declare no competing interests.

\section{References}

Acosta D, Alquizar ML, Junio C, Buladaco MV (2020, 2020) Correlational analysis of hot weather and number of recovery of the pandemic coronavirus in the Philippines. Mark Van, Correlational Analysis of Hot Weather and Number of Recovery of the Pandemic Coronavirus in The Philippines. https://doi.org/ $10.2139 / \mathrm{ssrn} .3597254$

Al-Ahmadi K, Al-Zahrani A (2013) Spatial autocorrelation of cancer incidence in Saudi Arabia. Int J Environ Res Public Health 10(12): 7207-7228. https://doi.org/10.3390/ijerph10127207

Altamimi A, Ahmed AE (2020) Climate factors and incidence of Middle East respiratory syndrome coronavirus. Journal of Infection and Public Health 13(5):704-708. https://doi.org/10.1016/j.jiph.2019. 11.011

Anchordoqui LA, Chudnovsky EM (2020) A physicist view of COVID19 airborne infection through convective airflow in indoor spaces. 
SciMedicine Journal 2:68-72. https://doi.org/10.28991/SciMedJ2020-02-SI-5

Anchordoqui LA, Dent JB, Weiler TJ (2020) A physics modeling study of SARS-CoV-2 transport in air. SciMedicine Journal 2:83-91. https://doi.org/10.28991/SciMedJ-2020-02-SI-7

Andronova NG, Schlesinger ME (2000) Causes of global temperature changes during the 19th and 20th centuries. Geophys Res Lett 27(14):2137-2140. https://doi.org/10.1029/2000GL006109

Azuma K, Kagi N, Kim H, Hayashi M (2020) Impact of climate and ambient air pollution on the epidemic growth during COVID-19 outbreak in Japan. Environ Res 190:110042. https://doi.org/10. 1016/j.envres.2020.110042

Barouki R, Kogevinas M, Audouze K, Belesova K, Bergman A, Birnbaum L et al (2021) The COVID-19 pandemic and global environmental change: emerging research needs. Environ Int 146 : 106272. https://doi.org/10.1016/j.envint.2020.106272

Bashir MF, Ma B, Komal B, Bashir MA, Tan D, Bashir M (2020) Correlation between climate indicators and COVID-19 pandemic in New York, USA. Sci Total Environ 728:138835. https://doi.org/ 10.1016/j.scitotenv.2020.138835

Bertram C, Luderer G, Creutzig F, Bauer N, Ueckerdt F, Malik A, Edenhofer O (2021) COVID-19-induced low power demand and market forces starkly reduce CO 2 emissions. Nat Clim Chang:14. https://doi.org/10.1038/s41558-021-00987-x

Bobylev SN (2020) Environmental consequences of COVID-19 on the global and Russian economics. Population and Economics 4:43-48. https://doi.org/10.3897/popecon.4.e53279

Bornstein MH (2020) Psychological insights for understanding COVID19 and families, parents, and children: Routledge.

Brassey J, Heneghan C, Mahtani KR, Aronson JK (2020) Do weather conditions influence the transmission of the coronavirus (SARSCoV-2)? Retrieved from https://www.cebm.net/covid-19/doweather-conditions-influence-the-transmission-of-the-coronavirussars-cov-2

Bruyninckx H. (2020) The European environment-state and outlook 2020: knowledge for transition to a sustainable Europe. Retrieved from $h$ ttps://www.eea.europa.eu/soer/2020

Bukhari Q, Massaro JM, D'agostino RB, Khan S (2020) Effects of weather on coronavirus pandemic. Int J Environ Res Public Health 17(15): 5399. https://doi.org/10.3390/ijerph17155399

Chakraborty I, Maity P (2020) COVID-19 outbreak: migration, effects on society, global environment and prevention. Sci Total Environ 138882:138882. https://doi.org/10.1016/j.scitotenv.2020.138882

Ching J, Kajino M (2020) Rethinking air quality and climate change after COVID-19. Int J Environ Res Public Health 17(14):5167

Cho R. (2020) COVID-19's long-term effects on climate change-for better or worse. Retrieved from https://blogs.ei.columbia.edu/ author/renee-cho/

Contreras LEV, Perkins KM, Ellenbecker M, Moure-Eraso R, Vega NEM (2021) COVID-19 pandemic lessons to facilitate future engagement in the global climate crisis. J Clean Prod 125178:125178. https://doi.org/10.1016/j.jclepro.2020.125178

Di Renzo L, Gualtieri P, Pivari F, Soldati L, Attinà A, Cinelli G et al (2020) Eating habits and lifestyle changes during COVID-19 lockdown: an Italian survey. J Transl Med 18(1):1-15. https://doi.org/ 10.1186/s12967-020-02399-5

Evans S (2020) Analysis: coronavirus set to cause largest ever annual fall in $\mathrm{CO} 2$ emissions. Carbon Brief 9

Fernández-Ahúja JML, Martínez JLF (2021) Effects of climate variables on the COVID-19 outbreak in Spain. Int J Hyg Environ Health 113723. https://doi.org/10.1016/j.ijheh.2021.113723

Friedlingstein P, O’Sullivan M, Jones MW, Andrew RM, Hauck J, Olsen A et al (2020) Global carbon budget 2020. Earth System Science Data 12(4):3269-3340. https://doi.org/10.18160/gcp-2020

Fritz S, See L, Carlson T, Haklay MM, Oliver JL, Fraisl D et al (2019) Citizen science and the United Nations sustainable development goals. Nature Sustainability 2(10):922-930. https://doi.org/10. 1038/s41893-019-0390-3

Gardner LM, Chughtai AA, MacIntyre CR (2016) Risk of global spread of Middle East respiratory syndrome coronavirus (MERS-CoV) via the air transport network. Journal of travel medicine 23(6) taw063. https://doi.org/10.1093/jtm/taw063

Garrett-Cox K. (2020) 5 steps businesses can take to protect air quality after COVID-19. Retrieved from https://www.cleanairfund.org/ blog-post/5-steps-businesses-can-take-to-protect-air-quality-aftercovid-19/

Ghebreyesus TA (2020) WHO manifesto for a healthy and green Covid19 recovery. Retrieved from https://www.who.int/news-room/ feature-stories/detail/who-manifesto-for-a-healthy-recovery-fromcovid-19

Harapan H, Itoh N, Yufika A, Winardi W, Keam S, Te H et al (2020) Coronavirus disease 2019 (COVID-19): a literature review. Journal of Infection and Public Health 13:667-673. https://doi.org/10.1016/ j.jiph.2020.03.019

Huang C, Wang Y, Li X, Ren L, Zhao J, Hu Y et al (2020) Clinical features of patients infected with 2019 novel coronavirus in Wuhan, China. Lancet 395(10223):497-506. https://doi.org/10. 1016/S0140-6736(20)30183-5

Hughes M. (2020) Evolving eating habits as a result of COVID-19. Retrieved from https://www.newfoodmagazine.com/article/ 109890/evolving-eating-habits-as-a-result-of-covid-19/

Ilesanmi O, Afolabi A (2020) Time to move from vertical to horizontal approach in our COVID-19 response in Nigeria. SciMedicine Journal 2:28-29. https://doi.org/10.28991/SciMedJ-2020-02-SI-3

Isaifan R (2020) The dramatic impact of Coronavirus outbreak on air quality: has it saved as much as it has killed so far? Global Journal of Environmental Science and Management 6(3):275-288. https:// doi.org/10.22034/GJESM.2020.03.01

Jones GS, Tett SF, Stott PA (2003) Causes of atmospheric temperature change 1960-2000: a combined attribution analysis. Geophys Res Lett 30(5). https://doi.org/10.1029/2002GL016377

Karimzadegan H, Rahmatian M, Farhud D, Yunesian M (2008) Economic valuation of air pollution health impacts in the Tehran area. Iran Iranian journal of public health:20-30

Khan N, Fahad S, Naushad M (2020) Climate impact on corona virus in the world. Retrieved from https://www.researchgate.net/publication/ 340488255

Kingham S. (2020) Climate explained: will the COVID-19 lockdown slow the effects of climate change? Retrieved from https://www. google.com/amp/s/theconversation.com/amp/climate-explainedwill-the-covid-19-lockdown-slow-the-effects-of-climate-change141604

Kumar A, Ayedee N (2021) An interconnection between COVID-19 and climate change problem. Journal of Statistics and Management Systems 24:1-20. https://doi.org/10.1080/09720510.2021.1875568

Le Quéré C, Peters GP, Friedlingstein P, Andrew RM, Canadell JG, Davis SJ et al (2021) Fossil CO 2 emissions in the post-COVID19 era. Nat Clim Chang 11(3):197-199. https://doi.org/10.1038/ s41558-021-01001-0

Luan PT, Ching CT-S (2020) A reusable mask for coronavirus disease 2019 (COVID-19). Arch Med Res 51:455-457. https://doi.org/10. 1016/j.arcmed.2020.04.001

Manzanedo RD, Manning P (2020) COVID-19: lessons for the climate change emergency. Sci Total Environ 742:140563. https://doi.org/ 10.1016/j.scitotenv.2020.140563

Marazziti D, Cianconi P, Mucci F, Foresi L, Chiarantini C, Della Vecchia A (2021) Climate change, environment pollution, Covid-19 pandemic and mental health. Sci Total Environ 145182:145182. https://doi.org/10.1016/j.scitotenv.2021.145182

Mehmood K, Bao Y, Abrar MM, Petropoulos GP, Soban A, Saud S et al (2021) Spatiotemporal variability of COVID-19 pandemic in relation to air pollution, climate and socioeconomic factors in Pakistan. 
Chemosphere 271:129584. https://doi.org/10.1016/j.chemosphere. 2021.129584

Minawi M. (2020) 5 ways COVID-19 has impacted MENA's food habits. Retrieved from https://www.ipsos.com/en-sa/5-ways-covid19-has-impacted-menas-food-habits

Morrison R. (2020) Air pollution across Europe. Retrieved from https:// www.dailymail.co.uk/sciencetech/article-8225373/Air-pollutionEurope-remains-45-cent-coronavirus-quarantine.html

Muhammad S, Long X, Salman M (2020) COVID-19 pandemic and environmental pollution: a blessing in disguise? Sci Total Environ 138820:138820. https://doi.org/10.1016/j.scitotenv.2020.138820

NASA. (2020) Nitrogen dioxide levels rebound in China. Retrieved from https:/earthobservatory.nasa.gov/images/146741/nitrogen-dioxidelevels-rebound-in-china

Negev M, Dahdal Y, Khreis H, Hochman A, Shaheen M, Jaghbir MT et al (2021) Regional lessons from the COVID-19 outbreak in the Middle East: from infectious diseases to climate change adaptation. Sci Total Environ 768:144434. https://doi.org/10.1016/j.scitotenv. 2020.144434

Nguyen XP, Hoang AT, Ölçer AI, Huynh TT (2021) Record decline in global $\mathrm{CO} 2$ emissions prompted by COVID-19 pandemic and its implications on future climate change policies. Energy Sources, Part A: Recovery, Utilization, and Environmental Effects:1-4. https:/ doi.org/10.1080/15567036.2021.1879969

Nicola M, Alsafi Z, Sohrabi C, Kerwan A, Al-Jabir A, Iosifidis C et al (2020) The socio-economic implications of the coronavirus pandemic (COVID-19): a review. International journal of surgery (London, England) 78:185. https://doi.org/10.1016/j.ijsu.2020.04. 018

Pearson PJ, Foxon TJ (2012) A low carbon industrial revolution? Insights and challenges from past technological and economic transformations. Energy Policy 50:117-127. https://doi.org/10.1016/j.enpol. 2012.07.061

Rasheed MAA, Farooque MMJ, Acharya HS, Quadri MSA (2021) Mathematical modelling of the relationship between two different temperament classifications: during the Covid-19 pandemic. Emerging Science Journal 5(1):67-76. https://doi.org/10.28991/ esj-2021-01258

Rickenbacker HJ, Collinge WO, Hasik V, Ciranni A, Smith I, Colao P, Sharrard AL, Bilec MM (2020) Development of a framework for indoor air quality assessments in energy conservation districts. Sustain Cities Soc 52:101831. https://doi.org/10.1016/j.scs.2019. 101831

Roser M, Ritchie H, Ortiz-Ospina E, Hasell J (2020). Coronavirus pandemic (COVID-19). Our world in data.
Saadat S, Rawtani D, Hussain CM (2020) Environmental perspective of COVID-19. Sci Total Environ 138870:138870. https://doi.org/10. 1016/j.scitotenv.2020.138870

Shen W, Yang C, Gao L (2020) Address business crisis caused by COVID-19 with collaborative intelligent manufacturing technologies. IET Collaborative Intelligent Manufacturing 2(2):96-99. https://doi.org/10.1049/iet-cim.2020.0041

Stern DI, Kaufmann RK (2014) Anthropogenic and natural causes of climate change. Clim Chang 122(1-2):257-269. https://doi.org/10. 1007/s10584-013-1007-x

Stevenson D, Johnson C, Collins W, Derwent R, Shine K, Edwards J (1998) Evolution of tropospheric ozone radiative forcing. Geophys Res Lett 25(20):3819-3822. https://doi.org/10.1029/ 1998GL900037

Su Z, Wang J, Klein P, Thompson AF, Menemenlis D (2018) Ocean submesoscales as a key component of the global heat budget. Nat Commun 9(1):1-8. https://doi.org/10.1038/s41467-018-02983-w

Taylor K (2014) Rapid climate change: new evidence shows that earth's climate can change dramatically in only a decade. Could greenhouse gases flip that switch? Am Sci 87(4):320-327

Tett SF, Stott PA, Allen MR, Ingram WJ, Mitchell JF (1999) Causes of twentieth-century temperature change near the Earth's surface. Nature 399(6736):569-572. https://doi.org/10.1038/21164

Tian H, Liu Y, Li Y, Wu C-H, Chen B, Kraemer MU et al (2020) An investigation of transmission control measures during the first 50 days of the COVID-19 epidemic in China. Science 368(6491): 638-642. https://doi.org/10.1126/science.abb6105

Usman M, Ali Y, Riaz A, Riaz A, Zubair A (2020) Economic perspective of coronavirus (COVID-19). J Public Aff 20(4):e2252. https://doi. org/10.1002/pa.2252

WHO. (2016) Ambient air pollution: a global assessment of exposure and burden of disease

Wood RA, Keen AB, Mitchell JF, Gregory JM (1999) Changing spatial structure of the thermohaline circulation in response to atmospheric CO 2 forcing in a climate model. Nature 399(6736):572-575. https://doi.org/10.1038/21170

Wu X, Nethery R (2020) Coronavirus and air pollution. Retrieved from https://www.hsph.harvard.edu/c-change/subtopics/coronavirusand-pollution/

Wu X, Nethery RC, Sabath BM, Braun D, Dominici F (2020) Exposure to air pollution and COVID-19 mortality in the United States. medRxiv. doi:https://doi.org/10.1101/2020.04.05.20054502

Publisher's note Springer Nature remains neutral with regard to jurisdictional claims in published maps and institutional affiliations. 